\title{
Role of cationic drug-sensitive transport systems at the blood-cerebrospinal fluid barrier in para-tyramine elimination from rat brain
}

Shin-ichi Akanuma ${ }^{\dagger}$, Yuhei Yamazaki ${ }^{\dagger}$, Yoshiyuki Kubo and Ken-ichi Hosoya*

\begin{abstract}
Background: para-Tyramine ( $p$-TA) is a biogenic amine which is involved in multiple neuronal signal transductions. Since the concentration of $p$-TA in dog cerebrospinal fluid (CSF) has been reported to be greater than that in plasma, it is proposed that clearance of cerebral $p$-TA is important for normal function. The purpose of this study was to examine the role of the blood-brain barrier and blood-cerebrospinal fluid barrier (BCSFB) in $p$-TA clearance from the brain.

Methods: In vivo $\left[{ }^{3} \mathrm{H}\right] p$-TA elimination from rat cerebral cortex and from CSF was examined after intracerebral and intracerebroventricular administration, respectively. To evaluate BCSFB-mediated $p$-TA transport, $\left[{ }^{3} \mathrm{H}\right] p$-TA uptake by isolated rat choroid plexus and conditionally immortalized rat choroid plexus epithelial cells, TR-CSFB3 cells, was performed.

Results: The half-life of $\left.{ }^{3} \mathrm{H}\right] p$-TA elimination from rat CSF was found to be $2.9 \mathrm{~min}$, which is 62 -fold faster than that from rat cerebral cortex. In addition, this $\left[{ }^{3} \mathrm{H}\right] p$-TA elimination from the CSF was significantly inhibited by co-injection of excess unlabeled $p$-TA. Thus, carrier-mediated $p$-TA transport process(es) are assumed to take part in $p$-TA elimination from the CSF. Since it is known that transporters at the BCSFB participate in compound elimination from the $C S F,\left[{ }^{3} \mathrm{H}\right] p$-TA transport in ex vivo and in vitro models of rat BCSFB was examined. The $\left[{ }^{3} \mathrm{H}\right] p$-TA uptake by isolated rat choroid plexus and TR-CSFB3 cells was time-dependent and was inhibited by unlabeled $p$-TA, indicating carriermediated $p$-TA transport at the BCSFB. The $p$-TA uptake by isolated choroid plexus and TR-CSFB3 cells was not reduced in the absence of extracellular $\mathrm{Na}^{+}$and $\mathrm{Cl}^{-}$, and in the presence of substrates of typical organic cation transporters. However, this $p$-TA uptake was significantly inhibited by cationic drugs such as propranolol, imipramine, amantadine, verapamil, and pyrilamine. Moreover, $p$-TA uptake by TR-CSFB3 cells took place in an oppositely-directed $\mathrm{H}^{+}$gradient manner. Therefore, this suggested that $p$-TA transport at the BCSFB involves cationic drug-sensitive transport systems which are distinct from typical plasma membrane organic cation transporters.
\end{abstract}

Conclusion: Our study indicates that $p$-TA elimination from the CSF is greater than that from the cerebral cortex. Moreover, it is suggested that cationic drug-sensitive transport systems in the BCSFB participate in this $p$-TA elimination from the CSF.

Keywords: Biogenic amine, Blood-cerebrospinal fluid barrier, Blood-brain barrier, Choroid plexus, Clearance, Transporter, para-tyramine, $p$-TA

\section{Background}

para-Tyramine ( $p$-TA) is one of the trace amines derived from tyrosine and present in fermented foods such as

\footnotetext{
*Correspondence: hosoyak@pha.u-toyama.ac.jp

'Shin-ichi Akanuma and Yuhei Yamazaki contributed equally to this work Department of Pharmaceutics, Graduate School of Medicine and Pharmaceutical Sciences, University of Toyama, 2630 Sugitani, Toyama 930-0194, Japan
}

cheese $[1,2]$. In the brain, $p$-TA acts as a neuromodulator, which supports neuronal actions by several neurotransmitters such as L-glutamate and norepinephrine [3, 4]. In addition, $p$-TA binds to trace amine-associated receptor 1 , which is a G protein-coupled receptor and is a therapeutic target for schizophrenia [5]. It has been reported that, after activating the receptor, serotonergic and dopaminergic neuronal actions via serotonin receptor $1 \mathrm{~A}$ and presynaptic 
dopamine D2 receptor, respectively, are reduced [6-10]. Since $p$-TA has a variety of roles in neuronal signal transduction, it is important to understand the homeostatic systems governing the $p$-TA concentration in the brain.

It is considered that the neural concentration of $p$ TA is maintained by a balance between production and clearance and there are reports that the activity of in vivo blood-to-brain transport of $p$-TA is low [11, 12]. In addition, Faraj et al. [13] have shown that the $p$ TA concentration in the cerebrospinal fluid (CSF) of dogs is approximately 2.6 -fold lower than that in plasma although $p$-TA is produced in the brain. Therefore, it is conceivable that the $p$-TA clearance from the brain is relatively greater compared with that of $p$-TA production. Regarding the metabolic pathway of $p$-TA, it is known to be metabolized to octopamine and $p$-hydroxyphenylacetate via dopamine $\beta$-hydroxylase and monoamine oxidase, respectively [14]. Brain barriers are involved in the clearance of several neural compounds: the bloodbrain barrier (BBB), which is formed by brain capillary endothelial cells, directly separates the brain from the circulating blood [15]. In addition, the cerebrospinal fluid (CSF) is separated from the circulating blood by the blood-CSF barrier (BCSFB) composed of choroid plexus epithelial cells [15]. Recent reports have shown that these barriers play a role in brain-to-blood transport of endogenous anionic and cationic compounds such as homovanillic acid and histamine [16, 17]. Therefore, there is a possibility that the BBB and/or BCSFB transport $p$-TA from the brain to the circulating blood and play a role in the $p$-TA clearance system in the brain.

These cells express a variety of plasma membrane transporters which contribute to compound transport across the BBB and BCSFB. In rat brain capillary endothelial cells, mRNAs of serotonin transporter [SERT/solute carrier (Slc) 6a4], organic cation transporter 1-3 (OCT1-3/ Slc22a1-3), multidrug and toxin extrusion 1-2 (MATE1-2/Slc47a1-2), organic cation/carnitine transporter 1-2 (OCTN1-2/Slc22a4-5), and plasma membrane monoamine transporter (PMAT/Slc29a4) have been reported to be expressed [18, 19]. Among these transporters, it has been demonstrated that PMAT is involved in 1-methyl-4-phenylpyridinium $\left(\mathrm{MPP}^{+}\right)$efflux transport at the $\mathrm{BBB}$, at least in part [18]. Regarding the BCSFB, the mRNA expression of these transporters has also been reported [18]. In addition, our previous studies have shown that PMAT and OCT3 are involved in the elimination of histamine and creatinine, respectively, from rat CSF $[16,20]$. Taking these reports into consideration, it is possible that several cationic transporters at these brain barriers take part in the clearance of cationic compounds from the brain. It is known that $p$-TA is a substrate of plasma membrane transporters, such as
SERT, OCT3, PMAT, and dopamine transporter (DAT/ Slc6a3) [21-24] and, thus, it is hypothesized that $p$-TA in the brain is eliminated via these plasma membrane transporters at the brain barriers.

To increase our knowledge of the homeostatic mechanism(s) governing the cerebral $p$-TA concentration, the purpose of this study was to examine the role of the brain barriers in $p$-TA clearance from the brain. To examine $p$-TA elimination across the $\mathrm{BBB}$, we used an intracerebral microinjection technique. To evaluate BCSFB-mediated $p$-TA efflux transport, in vivo intracerebroventricular administration and ex vivo transport studies using isolated choroid plexus were performed. In addition, the properties of $p$-TA uptake were examined using an in vitro model of rat BCSFB, conditionally immortalized rat choroid plexus epithelial cells (TR-CSFB3 cells).

\section{Methods}

\section{Reagents}

Butanol, $n\left[1-{ }^{14} \mathrm{C}\right]\left(\left[{ }^{14} \mathrm{C}\right] n\right.$-butanol, $\left.2 \mathrm{mCi} / \mathrm{mmol}\right)$, mannitol, D- $\left[1-{ }^{14} \mathrm{C}\right]\left(\left[{ }^{14} \mathrm{C}\right] \mathrm{D}\right.$-mannitol, $\left.55 \mathrm{mCi} / \mathrm{mmol}\right)$, and tyramine hydrochloride, [ring-3,5- $\left.{ }^{3} \mathrm{H}\right]-\left(\left[{ }^{3} \mathrm{H}\right] p-\mathrm{TA}, 50 \mathrm{Ci} /\right.$ mmol) were obtained from American Radiolabeled Chemicals (St. Louis, MO, USA). All other reagents were commercially available.

\section{Animals}

Wistar rats (male, 6-week-old, $160 \mathrm{~g}$ ) were purchased from Japan SLC (Hamamatsu, Japan) and maintained in a controlled environment.

\section{In vivo technique for evaluating $p$-TA elimination across the BBB [25]}

Anesthetized rats, obtained by intraperitoneally injecting pentobarbital sodium solution $(50 \mathrm{mg} / \mathrm{kg})$, were fixed in a stereotaxic apparatus (SR-5R; Narishige, Tokyo, Japan). Physiological buffer A $(0.5 \mu \mathrm{L} ; 122 \mathrm{mM}$ $\mathrm{NaCl}, 25 \mathrm{mM} \mathrm{NaHCO}, 10 \mathrm{mM}$ D-glucose, and $10 \mathrm{mM}$ 2-[4-(2-hydroxyethyl)-1-piperazinyl]ethansulfonic acid (HEPES)- $\mathrm{NaOH}, 3 \mathrm{mM} \mathrm{KCl}, 1.4 \mathrm{mM} \mathrm{CaCl}_{2}, 1.2 \mathrm{mM}$ $\left.\mathrm{MgSO}_{4}, 0.4 \mathrm{mM} \mathrm{K}_{2} \mathrm{HPO}_{4}, \mathrm{pH} 7.4\right)$ containing $\left[{ }^{3} \mathrm{H}\right] p-\mathrm{TA}$ $(120 \mathrm{nCi} / 0.5 \mu \mathrm{L}, 2.0 \mu \mathrm{M})$ and $\left[{ }^{14} \mathrm{C}\right] \mathrm{D}$-mannitol $(6.0$ $\mathrm{nCi} / 0.5 \mu \mathrm{L}, 220 \mu \mathrm{M})$ was injected into the parietal cortex area two region of the brain over a period of $1 \mathrm{~min}$. $\left[{ }^{14} \mathrm{C}\right] \mathrm{D}$-Mannitol, a BBB-impermeable marker, was used to normalize the actual injection volume. At a designated time, each rat was decapitated, and the ipsilateral cerebrum was removed. During the procedure, the behavior of rats and abnormal morphology of the brain was monitored, and there was no apparent change in the anesthetized conditions and brain structure. The tissue was dissolved in $2 \mathrm{~N} \mathrm{NaOH}(2 \mathrm{~mL})$ at $55^{\circ} \mathrm{C}$ for $3 \mathrm{~h}$ and then mixed with $10 \mathrm{~mL}$ Hionic-Fluor (PerkinElmer, Boston, MA, USA). The 
radioactivity was measured in a liquid scintillation counter equipped with an appropriate crossover correction for ${ }^{3} \mathrm{H}$ and ${ }^{14} \mathrm{C}$ (LSC-6101; Hitachi-Aloka Medical, Tokyo, Japan). The percentage of $\left[{ }^{3} \mathrm{H}\right] p$-TA remaining in the ipsilateral cerebrum (\%) was obtained from Eq. 1.

$\left[{ }^{3} \mathrm{H}\right] p$-TA remaining in the ipsilateral cerebrum (\%)

$$
=\frac{\left[{ }^{3} \mathrm{H}\right] p \text {-TA } /\left[{ }^{14} \mathrm{C}\right] D \text {-mannitol in the cerebrum }}{\left[{ }^{3} \mathrm{H}\right] p \text {-TA } /\left[{ }^{14} \mathrm{C}\right] D \text {-mannitol in the injectate }} \times 100
$$

Lateral ventricular micro-administration [26]

Rats were anesthetized by intraperitoneally injecting pentobarbital solution $(50 \mathrm{mg} / \mathrm{kg})$, and the head was fixed in the SR-5R (Narishige). A hole was drilled in the skull, $1.5 \mathrm{~mm}$ to the left and $0.5 \mathrm{~mm}$ posterior to the bregma, into which a needle was fixed as a cannula for injection. Then, $10 \mu \mathrm{L}$ buffer A containing $\left[{ }^{3} \mathrm{H}\right] p$-TA $(400 \mathrm{nCi})$ and $\left[{ }^{14} \mathrm{C}\right] \mathrm{D}$-mannitol $(5 \mathrm{nCi})$, with or without unlabeled $75 \mathrm{mM} p$-TA, was injected into the left lateral ventricle over a period of $20 \mathrm{~s}$. At designated times, CSF $(50 \mu \mathrm{L})$ was withdrawn by cisternal puncture and the levels of ${ }^{3} \mathrm{H}$ and ${ }^{14} \mathrm{C}$ in the CSF and injectate were measured in a liquid scintillation counter (LSC-6101; Hitachi-Aloka Medical). The rats exhibited no abnormal behavior during this technique.

The kinetic parameters of this study were obtained using a one-compartmental model (Eq. 2), where $C_{\mathrm{CSF}}(t)$, $k_{\mathrm{e}, \mathrm{CSF}}$, and $V_{\mathrm{d}, \mathrm{CSF}}$ are the concentration in CSF at time $t$, the elimination rate constant from the CSF, and the distribution volume in the CSF, respectively, of either $\left[{ }^{3} \mathrm{H}\right] p$-TA or $\left[{ }^{14} \mathrm{C}\right] \mathrm{D}$-mannitol.

$$
C_{\mathrm{CSF}}(t)=\frac{\text { Dose }}{V_{\mathrm{d}, \mathrm{CSF}}} \times \exp \left(-k_{\mathrm{e}, \mathrm{CSF}} \times t\right)
$$

In addition, " $C_{\mathrm{CSF}}(\mathrm{t}) /$ dose $\times 100$ " is the percentage of the residual concentration of the compound in the CSF normalized by the amount of injectate (\% of dose/mL CSF). By multiplying $k_{\mathrm{e}}$ by $V_{\mathrm{d}, \mathrm{CSF}}$, the apparent elimination clearance from the CSF $\left(C L_{\mathrm{CSF}}\right)$ was obtained.

\section{Transport study using choroid plexus [27]}

Rats were decapitated and the choroid plexus in the lateral ventricles was isolated. After preincubation of the choroid plexus in buffer A for $1 \mathrm{~min}$ at $37^{\circ} \mathrm{C}$, a transport reaction was initiated by applying buffer $\mathrm{A}$ containing
$1.0 \mu \mathrm{Ci}\left[{ }^{3} \mathrm{H}\right] p$-TA and $0.05 \mu \mathrm{Ci}\left[{ }^{14} \mathrm{C}\right] n$-butanol, a marker of water space in the choroid plexus [28], in the absence or presence of unlabeled compounds. $\mathrm{Na}^{+}$-free or $\mathrm{Cl}^{-}$-free buffer was prepared by equimolar replacement of $\mathrm{NaCl}$ and $\mathrm{NaHCO}_{3}$ with lithium chloride and potassium bicarbonate or that of $\mathrm{NaCl}, \mathrm{KCl}$, and $\mathrm{CaCl}_{2}$ with sodium gluconate, potassium gluconate, and calcium gluconate, respectively. At designated times, the uptake buffer was removed, and the choroid plexus was solubilized by adding $3 \mathrm{~N} \mathrm{KOH}$. A liquid scintillation cocktail (Hionic-Fluor; PerkinElmer) was added to the sample, and ${ }^{3} \mathrm{H}$ - and ${ }^{14} \mathrm{C}$-radioactivities were measured using an LSC-6101 (Hitachi-Aloka Medical).

\section{Uptake by conditionally immortalized rat choroid plexus epithelial cells [29]}

TR-CSFB3 cells were cultured at $33{ }^{\circ} \mathrm{C}$ as described previously. Kitazawa et al. have determined the apical localization of $\mathrm{Na}^{+}, \mathrm{K}^{+}$-ATPase from an immunocytochemical study using TR-CSFB3 cells cultured onto a glass slide [29]. It has also been demonstrated that the apical-tocell uptake capacity of $\left[{ }^{3} \mathrm{H}\right] \mathrm{L}$-proline in TR-CSFB3 cells seeded onto a Transwell ${ }^{\circledR}$ was similar to the uptake value of $\left[{ }^{3} \mathrm{H}\right] \mathrm{L}$-proline in TR-CSFB3 cells seeded onto a culture plate [29]. The cells were plated onto collagen I-coated 24-well culture plates (BD-Biosciences, Franklin Lakes, NJ, USA) at a density of $1.0 \times 10^{5}$ cells/well and cultured for 2 days at $33^{\circ} \mathrm{C}$. At $37^{\circ} \mathrm{C}$, the cells were washed three times with buffer $\mathrm{A}$ and $200 \mu \mathrm{L}\left[{ }^{3} \mathrm{H}\right] p$-TA-containing buffer A $(0.75 \mu \mathrm{Ci} / \mathrm{mL})$ was applied. $\mathrm{Na}^{+}{ }_{-}$or $\mathrm{Cl}^{-}$-free buffer A was prepared as described in the previous section. To stop the uptake reaction, cells were rinsed three times with $4{ }^{\circ} \mathrm{C}$ buffer $\mathrm{A}$. The cells were subsequently solubilized with $1 \mathrm{~N} \mathrm{NaOH}$ solution and incubated at room temperature for $12 \mathrm{~h}$. After neutralization with $1 \mathrm{~N} \mathrm{HCl}$, the cellular protein and $\left[{ }^{3} \mathrm{H}\right] p$-TA-derived radioactivity were determined using a detergent-compatible protein assay kit (BIO-RAD, Hercules, CA, USA) and liquid scintillation counting, respectively.

\section{Data analyses}

The distribution volume of $\left[{ }^{3} \mathrm{H}\right] p$-TA in isolated rat choroid plexus and TR-CSFB3 cells, namely the tissue/ medium ratio and cell/medium ratio, respectively, was obtained from the following equations (Eqs. 3, 4).

$$
\begin{aligned}
& \text { Tissue/ medium ratio }(\mu \mathrm{L} / \mu \mathrm{L} \mathrm{ChP}) \\
& =\frac{\left[{ }^{3} \mathrm{H}\right] p \text {-TA in the choroid plexus }(\mathrm{dpm} / \mathrm{ChP}) /\left[{ }^{3} \mathrm{H}\right] p \text {-TA concentration in buffer }(\mathrm{dpm} / \mu \mathrm{L})}{\left[{ }^{14} \mathrm{C}\right] n \text {-Butanol in the choroid plexus }(\mathrm{dpm} / \mathrm{ChP}) /\left[{ }^{14} \mathrm{C}\right] n \text {-Butanol concentration in buffer }(\mathrm{dpm} / \mu \mathrm{L})}
\end{aligned}
$$




$$
\text { Cell } / \text { medium ratio }(\mu \mathrm{L} / \mathrm{mg} \text { protein })=\frac{\text { Intracellular }\left[{ }^{3} \mathrm{H}\right] p \text {-TA per cellular protein amount }(\mathrm{dpm} / \mathrm{mg} \text { protein })}{\left[{ }^{3} \mathrm{H}\right] p \text {-TA concentration in buffer }(\mathrm{dpm} / \mu \mathrm{L})}
$$

The initial uptake clearance of $\left[{ }^{3} \mathrm{H}\right] p$-TA by isolated rat choroid plexus and TR-CSFB3 cells was calculated using Eqs. 5 and 6, respectively.

$$
\begin{aligned}
& \text { Tissue } / \text { medium ratio }(\mu \mathrm{L} / \mu \mathrm{L} \mathrm{ChP}) \\
& =\text { Initial uptake clearance }(\mu \mathrm{L} /(\min \mu \mathrm{L} \text { ChP })) \\
& \times \text { Time }(\min )+\text { Initial distribution volume } \\
& (\mu \mathrm{L} / \mu \mathrm{L} \text { ChP }) \\
& \text { Cell } / \text { medium ratio }(\mu \mathrm{L} / \mathrm{mg} \text { protein }) \\
& =\text { Initial uptake clearance } \\
& (\mu \mathrm{L} /(\text { min mg protein })) \times \text { Time }(\min ) \\
& + \text { Initial distribution volume } \\
& (\mu \mathrm{L} / \text { mg protein })
\end{aligned}
$$

The equation was fitted using the nonlinear leastsquares regression analysis program, MULTI [30]. To examine the initial uptake process, a linear correlation analysis was performed. The coefficient of determination $\left(r^{2}\right)$ of $\left[{ }^{3} \mathrm{H}\right] p$-TA uptake by isolated rat choroid plexus from $0.25 \mathrm{~min}$ to $1.0 \mathrm{~min}$ was found to be 0.981 , which was greater than that from $0.25 \mathrm{~min}$ to $2.0 \mathrm{~min}$ $\left(r^{2}=0.822\right)$. This suggested that the initial $\left[{ }^{3} \mathrm{H}\right] p$-TA uptake by isolated rat choroid plexus is reflected in the data up to $1 \mathrm{~min}$. Regarding the uptake of $\left[{ }^{3} \mathrm{H}\right] p$-TA by TR-CSFB3 cells, the $r^{2}$ of the $\left[{ }^{3} \mathrm{H}\right] p$-TA uptake from $0.25 \mathrm{~min}$ to $2.0 \mathrm{~min}$ was calculated as 0.989 , which is similar to that of $\left[{ }^{3} \mathrm{H}\right] p$-TA uptake by isolated rat choroid plexus from $0.25 \mathrm{~min}$ to $1.0 \mathrm{~min}$ and is close to 1 . This result suggests that the cell/medium ratio at all time points reflects the initial $\left[{ }^{3} \mathrm{H}\right] p$-TA uptake process.

The kinetic parameters for $p$-TA uptake by TR-CSFB3 cells were obtained from Eq. 7:

$$
V=\left(V_{\max } \times[\mathrm{S}]\right) /\left(K_{\mathrm{m}}+[\mathrm{S}]\right)+K_{\mathrm{d}} \times[\mathrm{S}]
$$

where $V$ is the uptake rate of $p$-TA, $[\mathrm{S}]$ is the $p$-TA concentration in buffer, $K_{\mathrm{m}}$ is the Michaelis-Menten constant, and $K_{\mathrm{d}}$ is the non-saturable transport clearance. The equation was fitted using the MULTI program [30]. The kinetic parameters are presented as the mean \pm standard deviation (S.D.). Other data represent the mean \pm standard error of the mean (S.E.M.). The statistical significance of differences between the means was determined using the unpaired Student's $t$ test for two groups and one-way analysis of variance followed by Dunnett's test for more than three groups.

\section{Results}

Evaluation of $p$-TA elimination from rat cerebral cortex

The time-course of the percentage $\left[{ }^{3} \mathrm{H}\right] p$-TA remaining in rat ipsilateral cerebrum at 5,10,20, and $40 \mathrm{~min}$ after microadministration into the parietal cortex area 2 is shown in Fig. 1a. There was no significant difference between the values at $5,10,20$, and $40 \mathrm{~min}(p=0.143)$, although a tendency for a time-dependent decrease was observed. As a reference value, the half-life $\left(t_{1 / 2}\right)$ of the percentage of cerebral $\left[{ }^{3} \mathrm{H}\right] p$-TA remaining after microinjection into the cerebral cortex was calculated to be $178 \pm 68 \mathrm{~min}$.

\section{In vivo $p$-TA elimination from rat CSF}

Figure $1 \mathrm{~b}$ shows the time profile of " $C_{\mathrm{CSF}}(\mathrm{t}) /$ dose $\times 100$ " values of $\left[{ }^{3} \mathrm{H}\right] p$-TA and $\left[{ }^{14} \mathrm{C}\right] \mathrm{D}$-mannitol after intracerebroventricular injection. The residual concentration in CSF of $\left[{ }^{3} \mathrm{H}\right] p$-TA at $1.0,1.5$, and 2.0 min was significantly lower than that of $\left[{ }^{14} \mathrm{C}\right] \mathrm{D}$-mannitol. $\left[{ }^{3} \mathrm{H}\right] p$-TA was eliminated from the CSF with a $t_{1 / 2}$ of $2.85 \pm 0.83 \mathrm{~min}$, which is 3.0-fold faster than the $t_{1 / 2}$ of $\left[{ }^{14} \mathrm{C}\right] \mathrm{D}$-mannitol. From the $V_{\mathrm{d}, \mathrm{CSF}}$ and $k_{\mathrm{e}, \mathrm{CSF}}$ values of $\left[{ }^{3} \mathrm{H}\right] p$-TA $\left(V_{\mathrm{d}, \mathrm{CSF}}\right.$, $159 \pm 16 \mu \mathrm{L} / \mathrm{rat} ; k_{\mathrm{e}, \mathrm{CSF}}, 2.43 \times 10^{-1} \pm 0.72 \times 10^{-1} \mathrm{~min}^{-}$ $\left.{ }^{1}\right)$, the $C L_{\mathrm{CSF}}$ of $\left[{ }^{3} \mathrm{H}\right] p$-TA was found to be $38.6 \pm 12.0 \mu \mathrm{L} /$ rat. The kinetic parameters for $\left[{ }^{14} \mathrm{C}\right] \mathrm{D}$-mannitol, $V_{\mathrm{d}, \mathrm{CSF}}$, $k_{\mathrm{e}, \mathrm{CSF}}$, and $C L_{\mathrm{CSF}}$, were calculated to be $135 \pm 11 \mu \mathrm{L} / \mathrm{rat}$, $8.07 \times 10^{-2} \pm 6.09 \times 10^{-2} \mathrm{~min}^{-1}$, and $10.9 \pm 8.3 \mu \mathrm{L} / \mathrm{rat}$, respectively. To examine the possible contribution of carrier-mediated $p$-TA elimination system(s) from the CSF, the effect of unlabeled excess $p$-TA on the concentration ratio of $\left[{ }^{3} \mathrm{H}\right] p$-TA and $\left[{ }^{14} \mathrm{C}\right] \mathrm{D}$-mannitol was examined. The $\left[{ }^{3} \mathrm{H}\right] p-\mathrm{TA} /\left[{ }^{14} \mathrm{C}\right] \mathrm{D}$-mannitol residual concentration ratio at 2 min was significantly (1.1-fold) increased by coadministration of $75 \mathrm{mM}$ unlabeled $p$-TA into the rat cerebroventricle compared with that in the control (Fig. 1c), indicating that $\left[{ }^{3} \mathrm{H}\right] p$-TA elimination from rat CSF was inhibited by excess unlabeled $p$-TA.

\section{$\left[{ }^{3} \mathrm{H}\right] p$-TA uptake by isolated rat choroid plexus}

In order to examine whether $p$-TA was eliminated from the CSF across the BCSFB, a $\left[{ }^{3} \mathrm{H}\right] p$-TA transport study using isolated rat choroid plexus was performed. $\left[{ }^{3} \mathrm{H}\right] p$-TA was time-dependently taken up into the isolated rat choroid plexus with an initial uptake rate and an initial distribution volume of $1.19 \pm 0.31 \mu \mathrm{L} /(\min \mu \mathrm{L}$ 

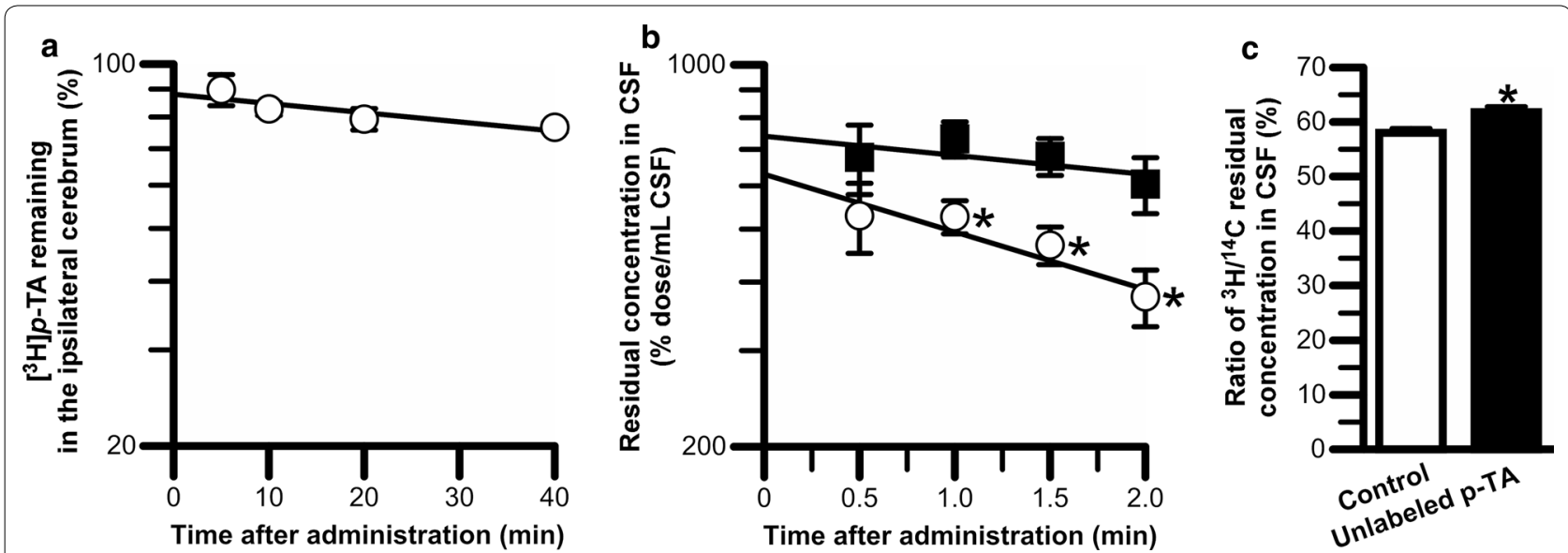

Fig. 1 In vivo analyses of $p$-TA elimination from rat brain or cerebrospinal fluid. a Time profile of [ ${ }^{3} \mathrm{H}$ ] $p$-TA remaining in the ipsilateral cerebrum after injection into rat cerebral cortex. A mixture of $\left[{ }^{3} \mathrm{H}\right] p-\mathrm{TA}(120 \mathrm{nCi})$ and $\left[{ }^{14} \mathrm{C}\right] \mathrm{D}$-mannitol $(6 \mathrm{nCi})$ dissolved in $0.5 \mu \mathrm{L}$ buffer $\mathrm{A}$ was injected. The solid line was obtained by MULTI analysis. Each point represents the mean \pm S.E.M. $(n=3)$. b Time profile of the residual CSF concentration (\% dose $\times 100)$ of $\left[{ }^{3} \mathrm{H}\right]$-TA (open circles) and $\left[{ }^{14} \mathrm{C}\right] \mathrm{D}$-mannitol (closed squares) after administration into rat lateral ventricles and sampled from the cisterna magna. Buffer A containing $\left[{ }^{3} \mathrm{H}\right]$ p-TA $(400 \mathrm{nCi} / 10 \mu \mathrm{L})$ and $\left[{ }^{14} \mathrm{C}\right] \mathrm{D}$-mannitol $(5 \mathrm{nCi} / 10 \mu \mathrm{L})$ was injected into rat lateral ventricles. The solid line was obtained by MULTI analysis. Each point represents the mean \pm S.E.M. $(n=3-4) .{ }^{*} p<0.05$, significantly different from the value for $\left[{ }^{14} \mathrm{C}\right] \mathrm{D}-\mathrm{mannitol}$. c Increase in the residual CSF concentration of $\left[{ }^{3} \mathrm{H}\right] p$-TA at 2 min normalized to that of $\left[{ }^{14} \mathrm{C}\right] \mathrm{D}$-mannitol by simultaneous administration of unlabeled 75 mM $p$-TA. Each column represents the mean \pm S.E.M. $(n=3-5) .{ }^{*} p<0.05$, significantly different from the control

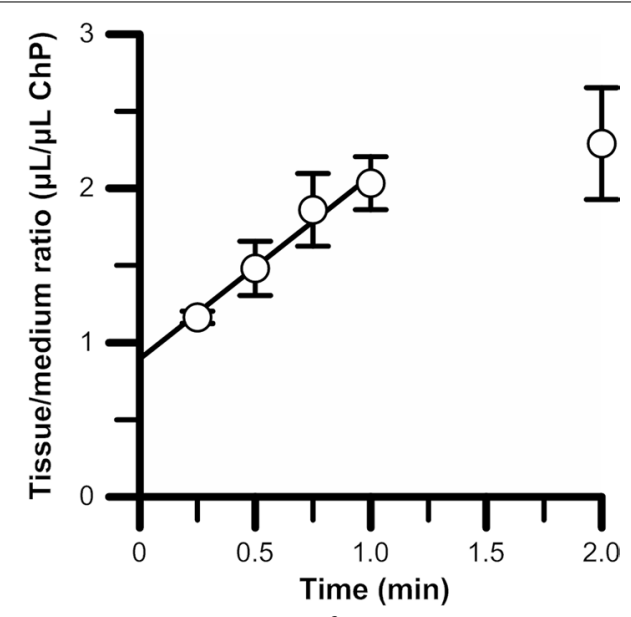

Fig. 2 Time-dependent uptake of $\left[{ }^{3} \mathrm{H}\right] p$-TA by isolated rat choroid plexus. The choroid plexus was incubated with $\left[{ }^{3} \mathrm{H}\right] p-\mathrm{TA}(1 \mu \mathrm{Ci} / \mathrm{sam}$ ple, $1 \mu \mathrm{M})$ and $\left[{ }^{14} \mathrm{C}\right] n$-butanol $(0.05 \mu \mathrm{Ci} /$ sample, $250 \mathrm{nM})$ at $37{ }^{\circ} \mathrm{C}$. The solid line was obtained by MULTI analysis. Each point represents the mean \pm S.E.M. $(n=3-6)$

ChP) and $0.895 \pm 0.223 \mu \mathrm{L} / \mu \mathrm{L}$ ChP, respectively (Fig. 2). As shown in Table 1, 10 mM unlabeled $p$-TA significantly inhibited this $\left[{ }^{3} \mathrm{H}\right] p$-TA uptake by $34 \%$. The absence of extracellular $\mathrm{Na}^{+}$or $\mathrm{Cl}^{-}$did not significantly affect the $\left[{ }^{3} \mathrm{H}\right] p$-TA uptake by isolated rat choroid plexus (Table 1 ), indicating that $\mathrm{Na}^{+}$and/or $\mathrm{Cl}^{-}$-cotransport systems are not involved in $p$-TA uptake by the rat choroid plexus. To examine $p$-TA transport mechanism(s) on the choroid plexus, the compound/drug-sensitivities to $\left[{ }^{3} \mathrm{H}\right] p$-TA uptake were examined (Table 1). Several cationic drugs, such as propranolol, pyrilamine, amantadine, imipramine, and verapamil, significantly inhibited $\left[{ }^{3} \mathrm{H}\right] p$-TA uptake by the isolated rat choroid plexus by more than 29\%. Among typical SLC transporter substrates/inhibitors, choline exhibited $28 \%$ inhibition of $\left[{ }^{3} \mathrm{H}\right] p$-TA uptake. However, $\left[{ }^{3} \mathrm{H}\right] p$-TA uptake by the isolated rat choroid plexus was not significantly altered in the presence of serotonin (a substrate of SERT), $\mathrm{MPP}^{+}$(a typical substrate of OCT and PMAT), tetraethylammonium (TEA; a typical substrate of OCT, OCTN, and MATE), and $p$-aminohippurate (PAH; a typical substrate of organic anion transporter, OAT).

\section{Characteristics of $\left[{ }^{3} \mathrm{H}\right] p$-TA uptake by TR-CSFB3 cells}

To clarify the characteristics of $p$-TA transport at the $\mathrm{BCSFB}$, a $\left[{ }^{3} \mathrm{H}\right] p$-TA transport study using an in vitro model of rat BCSFB, TR-CSFB3 cells, was performed. TR-CSFB3 cells exhibited time-dependent $\left[{ }^{3} \mathrm{H}\right] p$-TA uptake with an initial uptake rate and an initial distribution volume of $2.93 \pm 0.32 \mu \mathrm{L} /(\mathrm{min} \mathrm{mg}$ protein) and $2.25 \pm 0.24 \mu \mathrm{L} / \mathrm{mg}$ protein (Fig. 3a, open circles). At 2 min, $\left[{ }^{3} \mathrm{H}\right] p$-TA uptake by TR-CSFB3 cells at $4{ }^{\circ} \mathrm{C}$ was significantly reduced by $86 \%$ (Fig. $3 \mathrm{a}$, closed square). In addition, concentration-dependent $p$-TA uptake by TRCSFB3 cells consisted of saturable and non-saturable components with apparent $K_{\mathrm{m}}, V_{\max }$ and $K_{\mathrm{d}}$ values of $3.48 \pm 0.83 \mathrm{mM}, 7.26 \pm 1.61 \mathrm{nmol} /(\mathrm{min} \mathrm{mg}$ protein $)$, and $9.78 \times 10^{-1} \pm 0.66 \times 10^{-1} \mu \mathrm{L} /(\mathrm{min} \mathrm{mg}$ protein $)$, respectively (Fig. 3b). Moreover, $10 \mathrm{mM} p$-TA significantly 
Table 1 Effect of $\mathrm{Na}^{+}$- or $\mathrm{Cl}^{-}$-replacement, and co-presence of compounds on $\left[{ }^{3} \mathrm{H}\right] p$-TA uptake by isolated rat choroid plexus

\begin{tabular}{lll}
\hline Compounds & Concentration (mM) & Percentage of control \\
\hline $\mathrm{Na}^{+} / \mathrm{Cl}^{-}$-replacement & & $100 \pm 5$ \\
Control & & $93.6 \pm 3.9$ \\
$\mathrm{Na}^{+}$-free & $98.4 \pm 5.8$ \\
$\mathrm{Cl}^{-}$-free & \\
Co-presence of compounds & $100 \pm 9$ \\
Control & & $65.9 \pm 4.6^{* *}$ \\
p-TA & 10 & $61.0 \pm 5.4^{* *}$ \\
Propranolol & 10 & $61.2 \pm 0.8^{* *}$ \\
Pyrilamine & 10 & $61.4 \pm 0.6^{* *}$ \\
Amantadine & 10 & $67.4 \pm 1.1^{*}$ \\
Imipramine & 1 & $70.8 \pm 1.1^{*}$ \\
Verapamil & 1 & $72.3 \pm 4.6^{*}$ \\
Choline & 10 & $79.6 \pm 2.2$ \\
Serotonin & 10 & $84.7 \pm 6.3$ \\
MPP ${ }^{+}$ & 10 & $93.0 \pm 3.1$ \\
TEA & 10 & $95.4 \pm 5.1$ \\
PAH & 10 &
\end{tabular}

$\left[{ }^{3} \mathrm{H}\right] \mathrm{p}$-TA uptake by isolated rat choroid plexus $(1 \mu \mathrm{Ci} /$ sample) was performed at $37^{\circ} \mathrm{C}$ for $45 \mathrm{~s}$ in the absence (control) or presence of $\mathrm{Na}^{+}$and $\mathrm{Cl}^{-}$ without (control) or with unlabeled compounds. Each value represents the mean \pm S.E.M. $(n=3-8)$

$M P P^{+}$1-methyl-4-phenylpyridinium, $P A H$-aminohippurate, TEA tetraethylammonium, $p$-TA para-tyramine

${ }^{*} p<0.05$ and ${ }^{* *} p<0.01$, significantly different from control inhibited the $\left[{ }^{3} \mathrm{H}\right] p$-TA uptake by $48 \%$ (Table 2 ). $\left[{ }^{3} \mathrm{H}\right] p$-TA uptake by TR-CSFB3 cells was significantly inhibited by more than $30 \%$ in the presence of several kinds of cationic drugs/compounds, such as propranolol, imipramine, amantadine, nicotine, desipramine, pyrilamine, and verapamil. In contrast, this $\left[{ }^{3} \mathrm{H}\right] p$-TA uptake was not significantly altered by L-carnitine (a typical substrate of OCTN), pyrimethamine (a substrate of MATE), norepinephrine (a substrate of norepinephrine transporter), $\mathrm{PAH}$, serotonin, and cimetidine (a substrate of OCT and MATE). In addition, the $\left[{ }^{3} \mathrm{H}\right] p$-TA uptake by TR-CSFB3 cells was significantly increased, but not decreased, by the co-presence of tyrosine (a precursor of $p$-TA), choline (a substrate of OCT), $\mathrm{MPP}^{+}$, and TEA (Table 2).

The extracellular inorganic anion sensitivity of $\left[{ }^{3} \mathrm{H}\right] p$-TA uptake by TR-CSFB3 cells was examined and was found not to be altered in the absence of extracellular $\mathrm{Cl}^{-}$, whereas it was significantly increased, but not decreased, in the absence of extracellular $\mathrm{Na}^{+}$(Table 2). This result indicates that $\mathrm{Na}^{+}$- and $\mathrm{Cl}^{-}$-cotransporters are not involved in $p$-TA transport into the choroid plexus. The $\left[{ }^{3} \mathrm{H}\right] p$-TA uptake by TR-CSFB3 cells was significantly reduced by $50 \%$ at an extracellular $\mathrm{pH}$ of 6.0 (Fig. 4a, closed column), and increased 1.8-fold at an extracellular $\mathrm{pH}$ of 8.4 (Fig. 4a, hatched column). In order to examine the intracellular $\mathrm{pH}$ effect, TR-CSFB3 cells were treated with ammonium chloride, since the intracellular $\mathrm{pH}$ is increased by treatment with ammonium
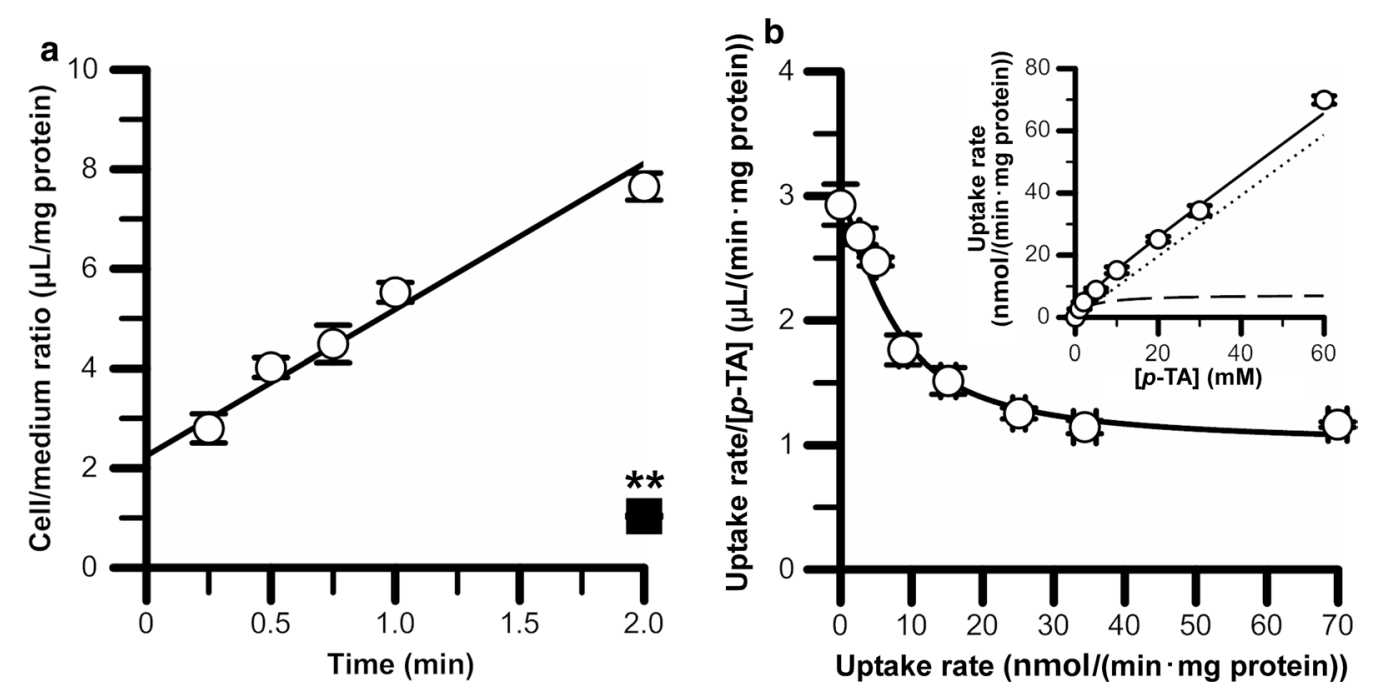

Fig. 3 Time-, temperature-, and concentration-dependence of $\left[{ }^{3} \mathrm{H}\right] p$-TA uptake by TR-CSFB3 cells. a $\left[{ }^{3} \mathrm{H}\right] p-T A$ uptake $(0.15 \mu \mathrm{Ci} /$ well, $19 \mathrm{nM})$ was measured at $37^{\circ} \mathrm{C}$ (open circles) and $4^{\circ} \mathrm{C}$ (closed square) for indicated times. The solid line was obtained by MULTI analysis. Each point represents the mean \pm S.E.M. $(n=3) .{ }^{* *} p<0.01$, significantly different from $\left[{ }^{3} \mathrm{H}\right] p$-TA uptake at $37^{\circ} \mathrm{C}$ for $2 \mathrm{~min}$. $\mathbf{b} p$-TA uptake, over the concentration range $20 \mathrm{nM}-60 \mathrm{mM}$, was measured at $37^{\circ} \mathrm{C}$ for $2 \mathrm{~min}$. The data were subjected to Eadie-Scatchard analysis in addition to Michaelis-Menten kinetics (inset). The solid, dashed, and dotted lines, which were fitted by the MULTI program, represent overall, saturable, and non-saturable transport, respectively. Each point represents the mean \pm S.E.M. $(n=3)$ 
Table 2 Effect of $\mathrm{Na}^{+}$- or $\mathrm{Cl}^{-}$-replacement, and co-presence of compounds on $\left[{ }^{3} \mathrm{H}\right] p$-TA uptake by TR-CSFB3 cells

\begin{tabular}{|c|c|c|}
\hline Compounds & Concentration (mM) & Percentage of control \\
\hline \multicolumn{3}{|l|}{$\mathrm{Na}^{+} / \mathrm{Cl}^{-}$-replacement } \\
\hline Control & & $100 \pm 3$ \\
\hline $\mathrm{Na}^{+}$-free & & $153 \pm 8^{* *}$ \\
\hline $\mathrm{Cl}^{-}$-free & & $103 \pm 4$ \\
\hline \multicolumn{3}{|c|}{ Co-presence of compounds } \\
\hline Control & & $100 \pm 1$ \\
\hline$p$-TA & 10 & $51.8 \pm 3.7^{* *}$ \\
\hline Propranolol & 10 & $29.0 \pm 4.2^{* *}$ \\
\hline Imipramine & 10 & $31.5 \pm 2.9^{* *}$ \\
\hline Amantadine & 10 & $45.3 \pm 2.4^{* *}$ \\
\hline Nicotine & 10 & $52.2 \pm 3.8^{* *}$ \\
\hline Desipramine & 10 & $63.4 \pm 1.9^{* *}$ \\
\hline Pyrilamine & 10 & $65.4 \pm 10.8^{* *}$ \\
\hline Verapamil & 3.0 & $69.6 \pm 6.7^{*}$ \\
\hline L-Carnitine & 10 & $75.0 \pm 5.7$ \\
\hline Norepinephrine & 10 & $96.1 \pm 7.3$ \\
\hline $\mathrm{PAH}$ & 10 & $110 \pm 6$ \\
\hline Serotonin & 10 & $114 \pm 5$ \\
\hline Cimetidine & 10 & $115 \pm 2$ \\
\hline Tyrosine & 10 & $140 \pm 17^{* *}$ \\
\hline Choline & 10 & $150 \pm 6^{* *}$ \\
\hline $\mathrm{MPP}^{+}$ & 10 & $155 \pm 19^{* *}$ \\
\hline TEA & 10 & $168 \pm 13^{* *}$ \\
\hline Control (1\% DMSO) & & $100 \pm 5$ \\
\hline $\begin{array}{l}\text { Pyrimethamine (1\% } \\
\text { DMSO) }\end{array}$ & 0.2 & $91.0 \pm 7.3$ \\
\hline
\end{tabular}

$\left[{ }^{3} \mathrm{H}\right] p$-TA uptake by TR-CSFB3 cells $\left(0.15 \mu \mathrm{Ci} /\right.$ well) was performed at $37^{\circ} \mathrm{C}$ for $2 \mathrm{~min}$ in the absence (control) or presence of $\mathrm{Na}^{+}$and $\mathrm{Cl}^{-}$without (control) or with unlabeled compounds. Each value represents the mean \pm S.E.M. $(n=3)$ $D M S O$ dimethyl sulfoxide, $M P P^{+}$1-methyl-4-phenylpyridinium, $P A H$ $p$-aminohippurate, TEA tetraethylammonium, $p$-TA para-tyramine ${ }^{*} p<0.05$ and ${ }^{* *} p<0.01$, significantly different from control

chloride (acute), and subsequent removal of ammonium chloride (pretreated) reduces the intracellular $\mathrm{pH}$ [31]. An increase in the intracellular $\mathrm{pH}$ significantly reduced $\left[{ }^{3} \mathrm{H}\right] p$-TA uptake by TR-CSFB3 cells at $\mathrm{pH} 7.4$ and $\mathrm{pH} 8.4$ by $37 \%$ and $42 \%$, respectively (Fig. $4 \mathrm{~b}$, acute and closed column), compared with respective untreated conditions (Fig. 4b, untreated and open column). In contrast, a reduction in intracellular $\mathrm{pH}$ increased $\left[{ }^{3} \mathrm{H}\right] p$-TA uptake by TR-CSFB3 cells to $126 \%$ and $191 \%$ at $\mathrm{pH} 7.4$ and $\mathrm{pH}$ 8.4, respectively (Fig. 4b, pretreated and hatched column), relative to the respective untreated conditions.

\section{Discussion}

In this study, $p$-TA elimination from the brain and CSF was investigated in rats (Fig. 1). To clarify the involvement of the BCSFB in $p$-TA elimination from the CSF, a
$p$-TA transport study using isolated rat choroid plexus, which forms the BCSFB, was carried out (Fig. 2 and Table 1). Since carrier-mediated transport properties were observed in this study using rat choroid plexus, $p$ TA transport characteristics were examined in in vitro rat BCSFB model cells (Figs. 3, 4, and Table 2).

The percentage of $\left[{ }^{3} \mathrm{H}\right] p$-TA remaining in the ipsilateral cerebrum tended to be reduced in a time-dependent manner (Fig. 1a), although there was no significant difference between the values at examined time points. It is known that $p$-TA is converted via enzymes in neural cells to several metabolites, such as octopamine [14]. Thus, it is suggested that $p$-TA and its metabolites are eliminated to a degree from the brain across the BBB. However, this $t_{1 / 2}$, as a reference record (178 $\left.\mathrm{min}\right)$, was 62 -fold longer than that of the residual concentration of $\left[{ }^{3} \mathrm{H}\right] p$-TA in the CSF (Fig. 1b). These results show that $p$-TA elimination from the CSF makes a major contribution to cerebral $p$ TA clearance relative to that from the brain parenchyma or interstitial fluid. In addition, the $C L_{\mathrm{CSF}}$ for $\left[{ }^{3} \mathrm{H}\right] p$-TA was 3.5 -fold higher than that of $\left[{ }^{14} \mathrm{C}\right] \mathrm{D}$-mannitol, a marker compound for bulk flow of CSF [26, 32]. Taking the inhibitory effect of $p$-TA elimination from the CSF by excess unlabeled $p$-TA (Fig. 1c) into consideration, this suggests that carrier-mediated transport system(s), which are distinct from CSF bulk flow, are involved in $p$ TA elimination from the CSF.

After intracerebroventricular administration, it is possible that $\left[{ }^{3} \mathrm{H}\right] p$-TA is distributed to the brain parenchyma and/or taken up into ependymal cells and choroid plexus epithelial cells [33]. It is known that transporters at the BCSFB participate in the elimination of several compounds from the CSF [15]. We have shown that $\left[{ }^{3} \mathrm{H}\right] p$-TA was time-dependently taken up into ex vivo isolated rat choroid plexus (Fig. 2) and in vitro choroid plexus epithelial cells, which form the BCSFB (Fig. 3). In addition, this $\left[{ }^{3} \mathrm{H}\right] p$-TA uptake was significantly inhibited by unlabeled $10 \mathrm{mM} p$-TA (Tables 1,2 ). Since the initial distribution volume of $p$-TA was found to be $159 \mu \mathrm{L}$ (Fig. 1b), the concentration in rat CSF of unlabeled $p$ TA after a $10 \mu \mathrm{L}$ intracerebroventricular microinjection of $75 \mathrm{mM}$ unlabeled $p$-TA was calculated to be $4.7 \mathrm{mM}$, which is similar to that in the in vitro self-inhibition studies. Therefore, it is suggested that some transport systems at the BCSFB take part in carrier-mediated elimination of $p$-TA from the CSF.

Since the apical membrane of the choroid plexus faces the $\left[{ }^{3} \mathrm{H}\right] p$-TA-containing buffer in the uptake study using isolated choroid plexus, it appears that the characteristics of $\left[{ }^{3} \mathrm{H}\right] p$-TA uptake by rat choroid plexus reflects the CSF-to-cell transport direction at the BCSFB. In this study, the choroid plexus from the lateral ventricle was used in the $p$-TA transport study. Although there are 

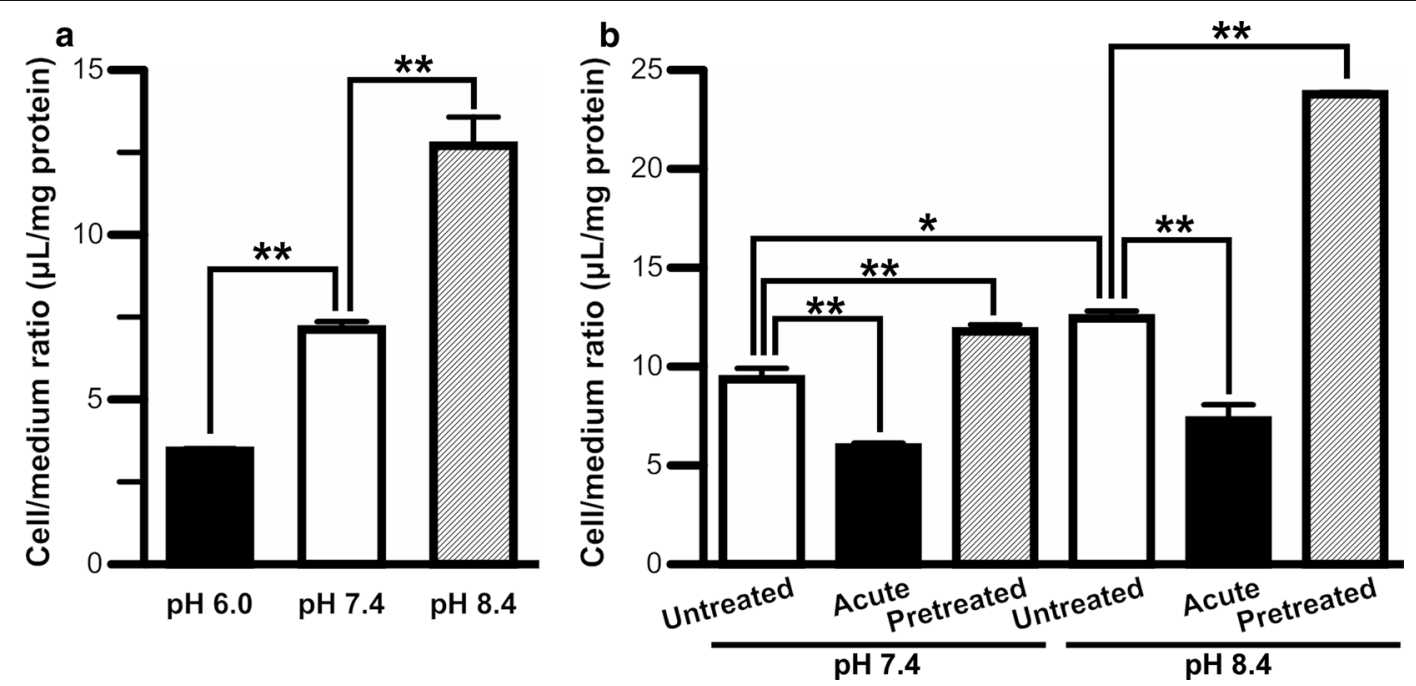

Fig. 4 Extra- and intra-cellular pH dependence of $\left[{ }^{3} \mathrm{H}\right] p$-TA uptake by TR-CSFB3 cells. a $\left.{ }^{3} \mathrm{H}\right] p$-TA uptake $(0.15 \mu \mathrm{Ci} /$ well) at $\mathrm{pH}$ 6.0, $\mathrm{pH} 7.4$, and $\mathrm{pH} 8.4$ was tested at $37^{\circ} \mathrm{C}$ for $2 \mathrm{~min}$. Each column represents the mean \pm S.E.M. $(n=3) .{ }^{* *} p<0.01$, significant difference between the groups. $\mathbf{b}$ TR-CSFB3 cells were preincubated with buffer $\mathrm{A}$ at $\mathrm{pH} 7.4$ or pH 8.4 in the absence (untreated and acute) or presence (pretreated) of $30 \mathrm{mM}$ ammonium chloride for $20 \mathrm{~min}$. After removal of the buffer, the cells were incubated with $\left[{ }^{3} \mathrm{H}\right] p-\mathrm{TA}(0.15 \mu \mathrm{Ci} /$ well) at pH 7.4 or pH 8.4 in the absence (untreated and pretreated) or presence (acute) of $30 \mathrm{mM}$ ammonium chloride at $37^{\circ} \mathrm{C}$ for $2 \mathrm{~min}$. Each column represents the mean $\pm \operatorname{SEM}(n=3-6) .{ }^{*} p<0.05$ and ${ }^{* *} p<0.01$, significant difference between the groups

known regional differences in physiological and transport functions between the choroid plexuses from the lateral, third, and fourth ventricles [34, 35], Ogawa et al. [26] have reported that the in vivo uptake rate which is extrapolated from in vitro benzylpenicillin transport in rat choroid plexus from the lateral ventricle, is in good agreement with that of saturable in vivo elimination of benzylpenicillin from the CSF. $p$-TA transport across the apical membrane of the isolated rat choroid plexus was found to be $7.14 \mu \mathrm{L} /(\mathrm{min}$ rat) since the total volume of rat choroid plexus has been reported to be $6 \mu \mathrm{L}(7.14 \mu \mathrm{L} /$ $($ min rat $)=1.19 \mu \mathrm{L} / \mu \mathrm{L} \mathrm{ChP} \times 6 \mu \mathrm{L} /$ rat $)[26]$. Regarding the polarity of TR-CSFB3 cells after seeding onto a culture plate and glass slide, it has been reported that membrane protein localization onto the plasma membrane of choroid plexus epithelial cells is mostly retained [29]. As the surface area of TR-CSFB3 cells and rat lateral ventricle choroid plexus epithelium has been reported to be $20 \mathrm{~cm}^{2} / \mathrm{mg}$ protein [18] and $75 \mathrm{~cm}^{2} /$ rat [36], respectively, the initial $p$-TA uptake clearance estimated from the uptake study using TR-CSFB3 cells was calculated to be $11.0 \mu \mathrm{L} /($ min rat $)(=2.93 \mu \mathrm{L} /($ min $\mathrm{mg}$ protein $) \div$ $20 \mathrm{~cm}^{2} / \mathrm{mg}$ protein $\times 75 \mathrm{~cm}^{2} /$ rat). This estimated initial $p$-TA uptake clearance from the transport study using TR-CSFB3 cells is consistent with that using isolated rat choroid plexus. Taking these findings into consideration, there is a high possibility that the characteristics of $p$ TA uptake by TR-CSFB3 cells reflect the $p$-TA transport properties of the apical membrane of the BCSFB.
These BCSFB-mediated $\left[{ }^{3} \mathrm{H}\right] p$-TA uptake clearance values obtained from the uptake studies of isolated rat choroid plexus $(7.14 \mu \mathrm{L} /(\mathrm{min}$ rat $)$ and TR-CSFB3 cells $(11.0 \mu \mathrm{L} /($ min rat $))$ were 18.5 and $28.5 \%$ of the in vivo total $\left[{ }^{3} \mathrm{H}\right] p$-TA elimination clearance from rat CSF (38.6 $\mu \mathrm{L} /($ min rat), Fig. $1 \mathrm{~b})$. As the elimination clearance of $\left[{ }^{14} \mathrm{C}\right]_{\mathrm{D}-m a n n i t o l}$ from rat CSF was found to be $10.9 \mu \mathrm{L}$ (Fig. 1b), $28.2 \%$ of the total $\left[{ }^{3} \mathrm{H}\right] p$-TA clearance would reflect the CSF bulk flow and diffusion to the brain parenchyma. As the other pathways for $p$-TA elimination from the CSF, the remainder of which corresponds to (43.3-53.5\%), the incorporation of $p$-TA into the neural cells facing the cerebroventricles, including the ependymal cells, is a possibility. Further analysis to check the radioactivities in choroid plexus and neural cells surrounding the cerebroventricle could help these cells contribute to $p$-TA elimination from the CSF. Nevertheless, it is considered that the BCSFB is involved in the carriermediated $p$-TA elimination from the CSF, at least in part, since an inhibitory effect of unlabeled excess $p$-TA on $\left[{ }^{3} \mathrm{H}\right] p$-TA uptake by isolated rat choroid plexus (Table 1) and TR-CSFB3 cells (Table 2) was observed.

$p$-TA uptake by TR-CSFB3 cells exhibited saturable and non-saturable kinetics (Fig. $3 \mathrm{~b}$ ). The clearance of the saturable process of $p$-TA transport $\left(V_{\max } / K_{\mathrm{m}}\right)$ was found to be $2.09 \mu \mathrm{L} /(\mathrm{min} \mathrm{mg}$ protein), which is 2.1 -fold higher than that of the non-saturable process $\left[K_{\mathrm{d}}, 0.978 \mu \mathrm{L} /\right.$ (min mg protein)]. This result indicates that the transporter-mediated process makes a major contribution to 
apical $p$-TA transport at the BCSFB. It has been reported that human OCT3 and PMAT accept $p$-TA as a substrate with a $K_{\mathrm{m}}$ of 0.281 and $283 \mu \mathrm{M}$, respectively [21, 22]. However, the $K_{\mathrm{m}}$ value of $p$-TA uptake by TR-CSFB3 cells $(3.48 \mathrm{mM})$ was inconsistent with these values. mRNA expression of OCT1-2, OCTN1-2, and MATE in addition to OCT3 and PMAT as typical organic cation transporters has been reported [18] but no attenuation of $\left[{ }^{3} \mathrm{H}\right] p$-TA transport into TR-CSFB3 cells and/or isolated rat choroid plexus was observed in the presence of these transporter inhibitors, such as $\mathrm{MPP}^{+}$, TEA, L-carnitine, pyrimethamine, and cimetidine (Tables 1,2 ). In summary, these lines of evidence suggest that typical organic cation transporters which are expressed in the BCSFB are not involved in $p$-TA transport across the BCSFB. Other plasma membrane transporters for $p$-TA are known: i.e. several $\mathrm{Na}^{+}-, \mathrm{Cl}^{-}$-dependent Slc molecules, such as DAT and SERT. However, in the uptake study using isolated rat choroid plexus and TR-CSFB3 cells, $\left[{ }^{3} \mathrm{H}\right] p$-TA uptake was not attenuated in the absence of extracellular $\mathrm{Na}^{+}$ and $\mathrm{Cl}^{-}$(Tables 1,2). The $K_{\mathrm{m}}$ value of human DAT- and SERT-mediated $p$-TA transport has been reported to be 1.7 and $52.7 \mu \mathrm{M}$, respectively [23, 24], which is different from the $K_{\mathrm{m}}$ value obtained for $p$-TA uptake by TR-CSFB3 cells. In addition, $\left[{ }^{3} \mathrm{H}\right] p$-TA uptake by both isolated rat choroid plexus and TR-CSFB3 cells was not significantly changed in the presence of serotonin, a substrate of SERT (Tables 1,2). Consequently, we conclude that typical organic cation transporters and the $\mathrm{Na}^{+}$- and $\mathrm{Cl}^{-}$-dependent Slc family do not play a role in apical $p$ TA transport at the BCSFB.

We showed that $p$-TA transport into TR-CSFB3 cells exhibited an oppositely-directed $\mathrm{H}^{+}$-gradient (Fig. 4). Cationic drug transport system(s) in several tissues and blood-central nervous system barriers have been proposed [37-43]. It has been reported that human intestinal epithelial cells transport several cationic drugs, such as bisoprolol and metoprolol, in an extracellular $\mathrm{pH}-$ dependent manner [37, 38]. Our previous reports have shown that nicotine is taken up into rat hepatocytes and lung via unidentified transport system(s) which recognize several cationic drugs and exhibit a $\mathrm{H}^{+}$/substrate antiport behavior $[39,40]$. Moreover, it has been shown that $\mathrm{H}^{+}$/ substrate antiport system(s) involve blood-to-brain transport across the BBB of cationic compounds and drugs, such as pyrilamine, oxycodone, and nicotine, although the molecular identification of the system(s) has not been reported [41-43]. $p$-TA uptake by isolated rat choroid plexus (Table 1) and TR-CSFB3 cells (Table 2) was significantly inhibited by cationic drugs which also inhibited the uptake of pyrilamine, oxycodone, and nicotine by an in vitro BBB model cell line $[41,42]$. Thus, it is suggested that cationic drug-sensitive transport system(s), similar to the systems in the BBB, are present on the apical membrane of the BCSFB and are involved in $p$-TA elimination across the BCSFB from the CSF.

In patients with Parkinson's disease and depression, monoamine oxidase inhibitors, such as selegiline, are regularly prescribed. It is widely known that patients who take $p$-TA-enriched foods exhibit neural side-effects such as migraine when receiving pharmacotherapy with monoamine oxidase inhibitors $[44,45]$. As one reason for the above side-effects, the activation of noradrenergic signal transduction has been proposed by monoamine oxidase inhibition and, thus, an increase in the neural $p$-TA concentration. Many monoamine oxidase inhibitors, including selegiline, are cationic and lipophilic drugs. This study has demonstrated that $p$-TA elimination across the BCSFB from the CSF is inhibited by cationic and lipophilic compounds (Tables 1,2). Thus, it is possible that the administration of cationic drugs causes an increase in $p$-TA in the brain via the inhibition of BCSFB-mediated $p$-TA elimination and exacerbates neuronal actions induced by excess $p$-TA. Further studies on the identification of $p$-TA transport molecule(s) which also recognize cationic drugs are needed, since this could help improve the pharmacotherapy of these patients in addition to increasing our understanding of the role of the BCSFB in homeostasis of $p$-TA levels in the brain. Moreover, it is considered that our findings about the in vitro characteristics of tyramine transport at the BCSFB (Tables 1, 2 ), such as inhibition by cationic drugs and promotion by the presence of several compounds (i.e., tyrosine, choline, $\mathrm{MPP}^{+}$, and TEA), are helpful for identifying the responsible molecule(s) for tyramine transport at the BCSFB.

\section{Conclusion}

Our study demonstrates the greater contribution of $p$-TA elimination from the CSF to the clearance of $p$-TA from the brain parenchyma in vivo. From the transport studies using isolated choroid plexus and TR-CSFB3 cells, $p$-TA efflux transport at the BCSFB was shown to involve cationic drug-sensitive transport systems. These are distinct from typical plasma membrane organic cation transporters in the BCSFB. This study provides a new view of the role of the BCSFB in homeostasis of trace amines in the brain, including $p$-TA.

\footnotetext{
Abbreviations

BBB: blood-brain barrier; BCSFB: blood-cerebrospinal fluid barrier; $C_{\mathrm{CSF}}(t)$ : concentration in CSF at time t; CSF: cerebrospinal fluid; DAT: dopamine transporter; DMSO: dimethyl sulfoxide; HEPES: 2-[4-(2-hydroxyethyl)-1-piperazinyl] ethansulfonic acid; $k_{\mathrm{e}, \text { CSF }}$ : elimination rate constant from the CSF; $K_{\mathrm{d}}$ : clearance of non-saturable transport; $K_{m}$ : Michaelis-Menten constant; MATE: multidrug and toxin extrusion; MPP ${ }^{+}$: 1-phenyl-4-phenylpyridinium; OCT: organic cation transporter; OCTN: organic cation/carnitine transporter; PMAT: plasma membrane monoamine transporter; $p$-TA: para-tyramine; [S]: the $p$-TA concentration in buffer; S.D.: standard deviation; S.E.M.: standard error of the mean; SERT:
} 
serotonin transporter; Slc: solute carrier; TR-CSFB: conditionally immortalized rat choroid plexus epithelial cells; $V$ : uptake rate; $V_{\mathrm{d}, \text { CSF }}$ : distribution volume in the CSF.

\section{Authors' contributions}

SA contributed to the design of this study, carried out the in vivo experiments, performed data collection and analysis, and drafted the manuscript. YY carried out most of the experiments. YK participated in the coordination of the study. $\mathrm{KH}$ took part in writing the manuscript. All authors read and approved the final manuscript

\section{Acknowledgements}

The authors thank Dr. Tetsuya Terasaki (Tohoku University, Sendai, Japan) for kindly supplying TR-CSFB3 cells and Mr. Hirokazu Shimada (University of Toyama, Toyama, Japan) for help with the in vitro methods used in this study.

\section{Competing interests}

The authors declare that they have no competing interests.

\section{Availability of data and materials}

The data sets used and/or analyzed during the current study are available from the corresponding author on request.

\section{Consent for publication}

N/A.

\section{Ethics approval and consent to participate}

All animal experiments in this study were approved by the Animal Care Committee of the University of Toyama (\#A2017PHA-6).

\section{Funding}

This research was supported by the Japan Society for the Promotion of Science (JSPS) KAKENHI [Grant Numbers JP16H05110 and JP16K08365] and the Research Grant from the Smoking Research Foundation.

\section{Publisher's Note}

Springer Nature remains neutral with regard to jurisdictional claims in published maps and institutional affiliations.

Received: 6 September 2017 Accepted: 20 December 2017

Published online: 08 January 2018

\section{References}

1. Borkum JM. Migraine triggers and oxidative stress: a narrative review and synthesis. Headache. 2016;56:12-35.

2. Ledonne A, Berretta N, Davoli A, Rizzo GR, Bernardi G, Mercuri NB. Electrophysiological effects of trace amines on mesencephalic dopaminergic neurons. Front Syst Neurosci. 2011;5:56.

3. Youdim MB, Weinstock M. Therapeutic applications of selective and nonselective inhibitors of monoamine oxidase $A$ and $B$ that do not cause significant tyramine potentiation. Neurotoxicology. 2004;25:243-50.

4. Revel FG, Moreau JL, Gainetdinov RR, Bradaia A, Sotnikova TD, Mory R, et al. TAAR1 activation modulates monoaminergic neurotransmission, preventing hyperdopaminergic and hypoglutamatergic activity. Proc Natl Acad Sci USA. 2011;108:8485-90.

5. Revel FG, Moreau JL, Pouzet B, Mory R, Bradaia A, Buchy D, et al. A new perspective for schizophrenia: TAAR1 agonists reveal antipsychotic- and antidepressant-like activity, improve cognition and control body weight. Mol Psychiatry. 2013;18:543-56.

6. Wolinsky TD, Swanson CJ, Smith KE, Zhong H, Borowsky B, Seeman P, et al. The Trace Amine 1 receptor knockout mouse: an animal model with relevance to schizophrenia. Genes Brain Behav. 2007;6:628-39.

7. Lindemann L, Meyer CA, Jeanneau K, Bradaia A, Ozmen L, Bluethmann H, et al. Trace amine-associated receptor 1 modulates dopaminergic activity. J Pharmacol Exp Ther. 2008;324:948-56.

8. Xie Z, Miller GM. Beta-phenylethylamine alters monoamine transporter function via trace amine-associated receptor 1: implication for modulatory roles of trace amines in brain. J Pharmacol Exp Ther. 2008:325:617-28.

9. Bradaia A, Trube G, Stalder H, Norcross RD, Ozmen L, Wettstein JG, et al. The selective antagonist EPPTB reveals TAAR1-mediated regulatory mechanisms in dopaminergic neurons of the mesolimbic system. Proc Natl Acad Sci USA. 2009;106:20081-6.

10. Leo D, Mus L, Espinoza S, Hoener MC, Sotnikova TD, Gainetdinov RR. Taar1-mediated modulation of presynaptic dopaminergic neurotransmission: role of D2 dopamine autoreceptors. Neuropharmacology. 2014;81:283-91.

11. Oldendorf WH. Brain uptake of radiolabeled amino acids, amines, and hexoses after arterial injection. Am J Physiol. 1971;221:1629-39.

12. James JH, Escourrou J, Fischer JE. Blood-brain neutral amino acid transport activity is increased after portacaval anastomosis. Science. 1978;200:1395-7.

13. Faraj BA, Camp VM, Ansley JD, Scott J, Ali FM, Malveaux EJ. Evidence for central hypertyraminemia in hepatic encephalopathy. J Clin Invest. 1981;67:395-402.

14. Berry MD. Mammalian central nervous system trace amines. Pharmacologic amphetamines, physiologic neuromodulators. J Neurochem. 2004;90:257-71.

15. Ohtsuki S, Terasaki T. Contribution of carrier-mediated transport systems to the blood-brain barrier as a supporting and protecting interface for the brain; importance for CNS drug discovery and development. Pharm Res. 2007;24:1745-58.

16. Usui T, Nakazawa A, Okura T, Deguchi Y, Akanuma SI, Kubo Y, et al. Histamine elimination from the cerebrospinal fluid across the blood-cerebrospinal fluid barrier: involvement of plasma membrane monoamine transporter (PMAT/SLC29A4). J Neurochem. 2016;139:408-18.

17. Mori S, Takanaga H, Ohtsuki S, Deguchi T, Kang YS, Hosoya K, et al. Rat organic anion transporter 3 (rOAT3) is responsible for brain-to-blood efflux of homovanillic acid at the abluminal membrane of brain capillary endothelial cells.J Cereb Blood Flow Metab. 2003:23:432-40.

18. Okura T, Kato S, Takano Y, Sato T, Yamashita A, Morimoto R, et al. Functional characterization of rat plasma membrane monoamine transporter in the blood-brain and blood-cerebrospinal fluid barriers. J Pharm Sci. 2011;100:3924-38.

19. Wakayama K, Ohtsuki S, Takanaga H, Hosoya K, Terasaki T. Localization of norepinephrine and serotonin transporter in mouse brain capillary endothelial cells. Neurosci Res. 2002:44:173-80.

20. Tachikawa M, Kasai Y, Takahashi M, Fujinawa J, Kitaichi K, Terasaki T, et al. The blood-cerebrospinal fluid barrier is a major pathway of cerebral creatinine clearance: involvement of transporter-mediated process. J Neurochem. 2008:107:432-42.

21. Chen L, Pawlikowski B, Schlessinger A, More SS, Stryke D, Johns SJ, et al. Role of organic cation transporter 3 (SLC22A3) and its missense variants in the pharmacologic action of metformin. Pharmacogenet Genom. 2010:20:687-99.

22. Engel K, Wang J. Interaction of organic cations with a newly identified plasma membrane monoamine transporter. Mol Pharmacol. 2005:68:1397-407.

23. Hilber B, Scholze P, Dorostkar MM, Sandtner W, Holy M, Boehm S, et al. Serotonin-transporter mediated efflux: a pharmacological analysis of amphetamines and non-amphetamines. Neuropharmacology. 2005:49:811-9.

24. Sitte HH, Huck S, Reither H, Boehm S, Singer EA, Pifl C. Carrier-mediated release, transport rates, and charge transfer induced by amphetamine, tyramine, and dopamine in mammalian cells transfected with the human dopamine transporter. J Neurochem. 1998;71:1289-97.

25. Kakee A, Terasaki T, Sugiyama Y. Brain efflux index as a novel method of analyzing efflux transport at the blood-brain barrier. J Pharmacol Exp Ther. 1996;277:1550-9.

26. Ogawa M, Suzuki H, Sawada Y, Hanano M, Sugiyama Y. Kinetics of active efflux via choroid plexus of beta-lactam antibiotics from the CSF into the circulation. Am J Physiol. 1994;266:R392-9.

27. Suzuki H, Sawada Y, Sugiyama Y, Iga T, Hanano M. Transport of benzylpenicillin by the rat choroid plexus in vitro. J Pharmacol Exp Ther. 1987:242:660-5.

28. Suzuki H, Sawada Y, Sugiyama Y, Iga T, Hanano M. Transport of cimetidine by the rat choroid plexus in vitro. J Pharmacol Exp Ther. 1986;239:927-35. 
29. Kitazawa T, Hosoya K, Watanabe M, Takashima T, Ohtsuki S, Takanaga H, et al. Characterization of the amino acid transport of new immortalized choroid plexus epithelial cell lines: a novel in vitro system for investigating transport functions at the blood-cerebrospinal fluid barrier. Pharm Res. 2001;18:16-22.

30. Yamaoka K, Tanigawara Y, Nakagawa T, Uno T. A pharmacokinetic analysis program (multi) for microcomputer. J Pharmacobiodyn. 1981;4:879-85.

31. Ohta KY, Inoue K, Hayashi Y, Yuasa H. Molecular identification and functional characterization of rat multidrug and toxin extrusion type transporter 1 as an organic cation $/ \mathrm{H}^{+}$antiporter in the kidney. Drug Metab Dispos. 2006;34:1868-74.

32. Suzuki H, Sawada Y, Sugiyama Y, Iga T, Hanano M. Saturable transport of cimetidine from cerebrospinal fluid to blood in rats. J Pharmacobiodyn. 1985:8:73-6.

33. Akanuma S, Sakurai T, Tachikawa M, Kubo Y, Hosoya K. Transporter-mediated L-glutamate elimination from cerebrospinal fluid: possible involvement of excitatory amino acid transporters expressed in ependymal cells and choroid plexus epithelial cells. Fluids Barriers CNS. 2015;12:11.

34. Quay WB. Regional differences in metabolism and composition of choroid plexuses. Brain Res. 1966;2:378-89.

35. Krunic N, Adamson SL, Coceani F. Differential uptake and catabolism of prostaglandin (PG)E(2) versus PGF(2alpha) in the sheep choroid plexus during development. Brain Res Dev Brain Res. 2000;119:11-9.

36. Keep RF, Jones HC. A morphometric study on the development of the lateral ventricle choroid plexus, choroid plexus capillaries and ventricular ependyma in the rat. Brain Res Dev Brain Res. 1990;56:47-53.

37. Fukao M, Ishida K, Horie A, Taguchi M, Nozawa T, Inoue H, et al. Variability of bioavailability and intestinal absorption mechanisms of metoprolol. Drug Metab Pharmacokinet. 2014;29:162-7.
38. Ishida K, Horie A, Nishimura M, Taguchi M, Fujii N, Nozawa T, et al. Variability of bioavailability and intestinal absorption characteristics of bisoprolol. Drug Metab Pharmacokinet. 2013;28:491-6.

39. Tega Y, Akanuma S, Kubo Y, Hosoya K. Involvement of the $\mathrm{H}^{+}$/organic cation antiporter in nicotine transport in rat liver. Drug Metab Dispos. 2015;43:89-92.

40. Tega Y, Yuzurihara C, Kubo Y, Akanuma SI, Ehrhardt C, Hosoya KI. Functional expression of nicotine influx transporter in A549 human alveolar epithelial cells. Drug Metab Pharmacokinet. 2016;31:99-101.

41. Tega Y, Akanuma S, Kubo Y, Terasaki T, Hosoya K. Blood-to-brain influx transport of nicotine at the rat blood-brain barrier: involvement of a pyrilamine-sensitive organic cation transport process. Neurochem Int 2013;62:173-81.

42. Okura T, Hattori A, Takano Y, Sato T, Hammarlund-Udenaes M, Terasaki T, et al. Involvement of the pyrilamine transporter, a putative organic cation transporter, in blood-brain barrier transport of oxycodone. Drug Metab Dispos. 2008;36:2005-13.

43. Yamazaki M, Fukuoka H, Nagata O, Kato H, Ito Y, Terasaki T, et al. Transport mechanism of an $\mathrm{H1}$-antagonist at the blood-brain barrier: transport mechanism of mepyramine using the carotid injection technique. Biol Pharm Bull. 1994;17:676-9.

44. Youdim MB, Bakhle YS. Monoamine oxidase: isoforms and inhibitors in Parkinson's disease and depressive illness. Br J Pharmacol. 2006;147(Suppl 1):S287-96.

45. Sathyanarayana Rao TS, Yeragani VK. Hypertensive crisis and cheese. Indian J Psychiatry. 2009;51:65-6.

\section{Submit your next manuscript to BioMed Central and we will help you at every step:}

- We accept pre-submission inquiries

- Our selector tool helps you to find the most relevant journal

- We provide round the clock customer support

- Convenient online submission

- Thorough peer review

- Inclusion in PubMed and all major indexing services

- Maximum visibility for your research

Submit your manuscript at www.biomedcentral.com/submit
() Biomed Central 